\title{
THE STYLES OF JAVANESE POLITICAL LEADERSHIP IN PRAMOEDYA ANANTA TOER'S NOVEL AROK DEDES
}

\author{
Yuhandri Pane, M. Manugeren, Purwarno Purwarno \\ English Department, Faculty of Literature \\ Universitas Islam Sumatera Utara \\ e-mail: yuhandripaness@gmail.com
}

Received: 2021-09-16

Accepted: 2021-11-05

\begin{abstract}
The research is focused on the styles of Javanese political leadership revealed in the novel Arok Dedes written by Pramoedya Ananta Toer. The Javanese leadership style is a cultural heritage and deserves to be maintained and revitalized and to be adjusted to the changing of times. Javanese people live side by side in harmony with cultural norms and values and lifestyle becomes an ethnic identity. The objectives are to find styles and how the styles of Javanese political leadership are revealed in Pramoedya Ananta Toer's novel Arok Dedes. A theory of Javanese leadership style, with its slogan of 5Ms is used a base and the whole research is conducted by means of descriptive qualitative method revealing the individual personality. The results show that the $5 \mathrm{Ms}$ of style are found in the novel: 1) melek/awas (awareness), 2) melik (sense of ownership), 3) muluk (poverty solution, 4) melok (aspiration realization), and 5) meluk (accomodation), all of which are performed by a leader of Tumapel district, named Ken Arok.
\end{abstract}

Keywords: cultural norms, ethnic identity, Javanese, leadership, individual personality

\section{Introduction}

Literary works have two important aspects, namely content and form. The content is in the form of human life experience, while the form is in the form of a way of assessment, namely the way of writers using beautiful language to accommodate the content (Semi, 1989) Meanwhile, Pradopo (2003) argues that literary works are created by authors inseparable from society and culture and in this case, writers often highlight the cultural richness of the people, ethnicity, or nation.

Other form of relation between literature and human existence is that the relation of literature to the psychological aspects. Literature and psychology are two branches of sciences that study human soul. Psychology deals to human behaviors and their effects while literature depicts human behavior through fiction. These two branches of social science studying human behavior are interrelated and mutually beneficial (Emir: 2016).

The psychological phenomena are also found in the novel Arok Dedes by Pramoedya Ananta Toer. The author creates the story based on the society and culture of the Javanese community of Indonesia. This novel takes its plot at Pekuwuhan Tumapel led by an Akuwu 'district leader', named Tunggul Ametung. The influence of Javanese tradition gives a great effect to the conflict found in the novel. At a glance, the 
characters in the novel such as Ken Arok, Ken Dedes, Tunggul Ametung remind us of the history of Singosari, one of the great kingdoms in Indonesian tradition history. The novel Arok Dedes is a story that raises the names of characters from the real world.

Arok Dedes, selected as the object of study, focused on the styles of Javanese political leadership, is based on the premise that this novel is the work of Pramoedya Ananta Toer which is very monumental and is considered a reflection of the history of domestic politics for many years. Arok leads Tumapel as a leader with his leadership skills which are inseparable from the concept of the philosophy of leadership in the Javanese people, after a coup against Tunggul Ametung, a leader considered a tyrant. Arok brings Tumapel to be a large kingdom called Singosari. Arok's leadership in the novel reflects his toughness as a leader. He embraces all components of society from the Shudras to the Brahmins to jointly fight for their rights as humans. This topic is related to the current political situations of the world.

\section{Literature Review}

This study, then, is conducted under the theory of psychology of literature related to the leadership in Pramoedya Ananta Toer's novel Arok Dedes, specifically on the Javanese leadership characteristics in the political aspects. Leadership connects to the ability of a leader in leading his followers, and there should be concept of style that a leader uses to do so.

\subsection{Psychology of Literature}

A literary works gives value to psychology in the form of presenting characters, particularly in expressing the moods, and bringing the reader into the psychological dimension of human reality. By this way, psychology and the study of literature share their focus on the emotions and human soul. Literature contains several phenomena related to the human soul. The author reflects the phenomena through characters in literary works. Literary psychology is defined as a discipline that views literary works as some events of human life played by imaginary characters or even factual characters (Sangidu, 2004:30).

Other close relationship between literature and psychology can be described in the way that psychology helps to clarify some literary problems, and literature presents insights to psychology. Further, according to Cohen (1997) in the effort to gain deeper understanding, literature can be studied by various approach including psychological approach. Conversely, Cohen (1997) assumes that the psychologist's manner of conceiving and representing the personality is supported by the intuitive representations made by novelists, dramatists, and other creative writers. Thus, psychological approach reflects the effect that modern psychology has had upon both literature and literary criticism.

Psychology and literature has deep connection in human life, since both of them deal with the human behaviors, expression, thought, and motivation. Kartono (1980) describes psychology as the science of human, broadly defined, as the scientific study of behavior, both external observable action and internal thought. In literary study, psychology can be used to explore, explain, and describe things and phenomena of human life by implementing the principle of psychology in the literary work. By using psychological approach, the relation among components found in the literary works can be chosen as topic for literature study. However, psychology is only preparatory to the act of creation, and in the work itself, psychological truth is an artistic value only if it 
enhances coherence complexity, in short; it is art (Wellek \& Warren, 1977). Psychology of literature then becomes a base for this study, since the explorations of leadership are linked with personality.

\subsection{Leadership}

A definition of leadership that would be widely accepted by the majority of theorists and researchers is a process of social influence in which one person is able to enlist the aid and support of others in the accomplishment of a common task. The major points of this definition are that leadership is a group activity, based on social influence, revolving around a common task. Although this specification seems relatively simple, the reality of leadership is very complex. Interpersonal factors (i.e., thoughts and emotions) interact with personal processes (i.e attraction, communication, influence) to have effects on a dynamic external environment. Each of these aspects brings complexity to the leadership process. (Chemers, 2014)).

Leadership itself has a specific function which is expected to gain benefits for human welfare, since leadership is an activity or art of influencing other people to want to work based on that person's ability to guide others in achieving the various goals desired by the group. Basically leadership is the science and art of influencing people or groups to act as expected in order to achieve goals effectively and efficiently. In this case, someone influences and motivates others to do something for the sake of achieving common goals. In other words, leadership is the art of influencing and mobilizing people in such a way as to gain moral obedience, trust, respect, and cooperation to complete common tasks that include the process of influencing in determining organizational goals, motivating follower behavior to achieve goals, influencing to improve the group and its culture.

The leader's character basically comes from the leader himself, the aura of the leader. Leadership's aura is an abstract thing that is difficult to explain, but can be seen in a leader. It is a combination of personal, interpersonal, and emotional intelligence qualities that are properly integrated within a person. The result of this combination will be seen in the work performance of the leader, and it sometimes does not have to be associated with fashion, title, or great work performance, but through self-confidence, poise, credibility, and charisma.

The confidence that a leader has can be used to more easily motivate and convince others, and even make them willing to take risks. However, there are times when someone is also experiencing a crisis of self-confidence; therefore, a special strategy is needed in maintaining self-confidence. Being elegant and taking control of communication is a strategy that can be done when someone loses self-confidence. Being elegant here means being able to appear calm and in control in an uncomfortable situation by understanding the reactions of others. In communicating, the credibility of a leader can be seen through the way he communicates, which can be seen from his body language which is in tune with verbal messages when speaking. With the ability to communicate, a leader can collaborate and provide motivation to followers. This ability can also be used to gain participation from followers and provide direction to them in achieving common goals.

\subsection{Character Values of Javanese Leader}

The development of psychological aspects of Javanese leaders is influenced by the Javanese cultures. The basis and thought in Javanese power are always related to 
leadership because that power lies very much with the leader. Power will cause the leader to have authority. Culture and leadership are very close and need each other. Endraswara (2013) argues that the cultural element is the most important variable in understanding the political development of a nation or society influenced by the values that exist in a particular society or nation. Further, culture in this case is the whole system of ideas, actions and human work in the context of social life which make the property of humans through the learning process. Culture itself has universal elements which are also the contents of the overall meaning of culture itself, namely: (a) religious systems and religious ceremonies, (b) systems of social organization, (c) systems of knowledge, (d) language systems, (e) ) an art system, (f) a livelihood system, and (g) a technology and equipment system (Endrawarsa, 2013).

Based on this framework, a discussion of the concept of leadership from the point of view of Javanese culture is conducted. This Javanese leadership style is used as a tool also to analyze the Javanese leadership style based on the fact that in political science, leadership and the symptoms associated with it are very important, because leadership shows the activities, behavior and attitudes and decisions of actors, groups, or organizations, more visible in the decision making to determine policy in leadership.

Since political leaders are elected rather than appointed, acting as representatives, they require consent from those whom they govern and serve. They have a duty to serve all their constituents and protect the interests of future generations, rather than simply those who support them. This should include the elderly and disadvantaged groups, as well as those who do not have the power to vote, such as children. These are typical differences in comparison with non-political leaders, but political leaders also operate under different structures of accountability and scrutiny. In addition, they have formal legal responsibility for a broad range of issues: health, law enforcement, taxation, education, legislation and the economic sphere. The networks within which they act have regularities but are also fluid. Political leaders gain authority through the ballot box initially but their authority is potentially subject to challenge on a daily basis, from: their political party, opposition, politicians, the media, their constituents, and other bodies.

\subsection{Javanese Political Leadership}

If viewed from a western point of view, that is the trait of leadership, then according to Davis (2003), there are 4 main characteristics that have an influence on leadership success in an organization, namely: a) intelligence, b) social maturity and broad social relationships, c) self-motivation and encouragement achievement, and d) human relationship attitude. While the characteristics of the leader according to Soetopo (2010) are: 1) symbolic leadership which has the characteristics: friendly, honest, passionate, creative, stoic, wise, intelligent, humorous, gentle, and some consider body shape. 2) formal leadership (because of position, title, title, top of hierarchy, power) and 3) functional leadership (because of the role, function, and benefits for the group).

The characteristics of Javanese power are attached to the leadership, so that someone becomes leaders will have high authority. The hallmarks of Javanese leadership in terms of succession, are among others (a) a replacement for the leadership must be purified for the sake of seeping honey, it means that heredity is very much considered. Breed is the main requirement in the world of Javanese leaders; (b) elected by the previous leader, by way of appointment, providing the criteria. The appointed leader cannot refuse, but must sendika dhawuh, which means that you must follow 
orders, (c) without periodical leadership, depending on whether the person concerned will step down or not. Further, Endraswara (2013) states that the characteristics of Javanese leadership are: monocentrum (single figure), metaphysical (revelation, pulung, drajat, descent / nunggak semi), pragmatic (nominating a leader with broto / male / ritual behavior), ethical (which is desirable to distinguish between good and bad), and syncretic (taking the concepts from various religions, namely Islam and Hinduism).

A figure who can lead Javanese people has 3 attitudes, namely: (a) protection (ngayomi) from various safety and comfort, (b) welfare (Ngayemi), all residents should always live sufficiently, not lacking of property, (c) ajur ajer, merging with the people. Javanese leader has a style. Style is a condition of cultural meaning which forms a new identity. Every leadership styles have different categorical values. That category also depends on conditions. The Javanese leadership styles are divided into 3 levels: (1) nistha (2) madya, and (3) utama (insult-middle-main). The most qualified one is the utama level. The virtue of the Javanese leader will be favored by the people. Javanese leadership style is known by the slogan of 5Ms, namely: 1) melek/awas (awareness), 2) melik (sense of ownership), 3) muluk (poverty solution), 4) melok (aspirations realization), and 5) meluk (accomidation) (Endraswara, 2013).

\section{Research Method}

This study is conducted by using descriptive qualitative research with text analysis design. Fraenkel and Wallen (2000) defines that descriptive method is a method used to explain, analyze and classify something through various techniques, survey, interview, questionnaires, observation, and text. So, in this study words, phrases, or sentences related to text of the topic of analysis found in the novel entitled Arok Dedes by Pramoedya Ananta Toer are used as the source of data. This qualitative design is used to describe the Javanese political leadership found in the novel as the major topic of analysis. The scripts of the novel are the primary data of the study, while the secondary data is other sources such as books, journal articles, and other related sources.

The data collection procedure is conducted by reading the novel, understanding the novels related to the Javanese political leadership, investing data (words, phrases, and sentences) related to the topic of analysis and classifying data according to the forms and the ways of how styles of Javanese political leadership are implied in the novel based on the concepts of leadership. In the data analysis procedure, three activities are conducted: data reduction, the process of selecting, identifying, classifying and coding the data; data display, referring to the process of simplifying the data in the form of sentences, or narration and conclusion drawing, based on validity and consistency criteria.

\section{Results and Discussions}

A discussion of the concept of leadership from the point of view of Javanese culture is presented here, based on the consideration of the assumption that the current system in Indonesia, especially the Indonesian political system, is almost completely influenced by the political system and the traditional power of Javanese culture.

\subsection{Melek/awas (Awareness)}

Melek means 'to see'. In addition, melek is to open the eyes, looking carefully, also meaning to be always alert. This style reflects the leader as a supervisor (controller) 
in order to bring his heart closer to the people. It also means that a leader must know and understand very well the conditions and problems faced by his people, so that he is able to find effective and precise solutions. By being melek, a leader also becomes an extraordinary recorder. In other word, melek also means wanting to know the developments in other parts of the world.

Melek style reflected by Ken Arok in the story is implied in monolog and dialogue. All of the expressions are based on Ken Arok personally. This shows his quality of awareness of his surrounding and also people around him. Arok's awareness not only implies big things, but also small things. Even he seems to have ability to know someone's intention by examining what is spoken or done by people around him.

"My opinion, unequivocally now, is: Father Mahaguru Dang Hyang

Lohgawe does not like Sri Sultan Kretajaya, especially his akuwu in

Tumapel, Tunggul Ametung ..." (Toer, 1999: 64)

Arok reveals his teacher's intention about Sri Baginda Kretajaya, and his akuwu of Tumapel, Tunggul Ametung. Arok has observed his teacher's statement about Sri Baginda Kretajaya and gives his conclusion that his teacher does not like his leadership of Kediri, especially his akuwu of Tumapel, Tunggal Ametung.

In another situation, Arok shows his melek quality during a meeting among the Mahaguru about their rebellion to the leadership of Tumapel. For Arok, what has been done by Mahaguru all this time has no sense.

"Interesting description, just no move without conclusion", Arok judged (Toer, 1999: 86)

Arok's awareness is also seen in protecting his soldiers. In the story, once Arok is sent to Tumapel under the order of his teacher, Lohgawe, to protect Prameswary of Tumapel, Ken Dedes. There is a situation when Arok orders his soldier not to give respond to anyone outside his side. It is because Tunggul Ametung starts to accuse Ken Arok as the man who starts a rebellion in Tumapel. Arok realizes that the people in Tumapel are suspicious of him and will use his men as a tool to find information about him. That is how Arok shows his melek.

Arok ordered all his men not to answer questions from strangers and those who were not from his own line. Precisely because of that order they were astonished to see how many people tried to talk to them (Toer, 1999: 37).

This action is also a solution to the problems in his group to avoid stumps of Ametung's suspicions of him and his soldiers. In other words, Arok is very aware of the threats that will occur in the group he leads, and tried to find solution of the situation.

As it has been stated that melek/awas does not only mean to open the eyes, looking carefully, but it also means to be always alert. The context of melek is very important to bring the hearts of leaders closer to the people. This situation is also implied by Arok in his style of leading and controlling his men. He does believe that whatever he does is because of Hyang Yama and does not violate the rules. That is what makes his soldiers so close to him and no one betrays him.

Until then, he still maintainsed his opinion: everything he had done so far has had violated Hyang Yama. The proof was that all of his friends were loyal to him. No one had ever betrayed him (Toer, 1999: 90). 
When Arok leads his troops in an attack in the southern area of Tumapel, there is a Tumapel's soldier who begs Arok's forgiveness and wants to join his army, but Arok does not accept it. For Arok, the soldier is a traitor, and a traitor is an enemy who must be watched at all times, and he does not need traitors in his army. This situation is implied in the dialogue between Arok and his army.

"They are Tumapel soldiers when they come to me. They have remained soldiers of Tumapel before joining Mundrayana. We are peasants, needing nothing but ourselves. He has to learn to understand" (Toer, 1999: 352).

\subsection{Melik ( sense of ownership)}

The second style is melik (sense of ownership). Melik means a leader must have a sense of belonging to his blood and his people. Melik must be distinguished from milik. Melik contains a message of belonging, so that they want to protect their subordinates, milik is actually a bad behavior. Melik makes personal leaders want to dominate, but for the benefit of their subordinates. If a leader already has an awareness of it, then a leader must go all out in maintaining the integrity of his homeland, as well as property; dignity; even the lives of the people they lead. Usually this melik feeling can develop into a nationalist.

Arok's melik is shown by his actions and appearance. Arok wears the symbols of Gods united on the necklace and on the hands, sparkling the light of the bonfire when people see it. This appearance becomes a symbol for him and also for people around him to show how much Arok feels that he is going to spill his blood, as the resistance he does against the untrustworthy leader, not only wanting to enrich himself.

Seeing the symbols of the gods united on the necklace and on the hands, gleaming in the rays of the bonfire, people fell on their knees on the ground with the tops of their noses touching the earth.

(Toer, 1999: 24).

In the story, the symbols used by Arok are markers of his identity as a person who loves his homeland. This symbol is often a frightening specter for his enemies, symbolizing someone who is willing to do anything for the sake of spilling his blood. In a dialogue quoted, Arok openly states how he is not afraid to defend Tumapel, even if he has to sacrifice his own life.

"Don't think that you can control the entire army of Tumapel. Look at this, Arok, who keeps Tumapel. He and his army will defend to the last drop of blood, not for money, gold, silver and thrones".

(Toer, 1999: 467).

This dialogue also shows that Arok's melik has led to a sense of nationalism which is an important point in this melik concept itself.

\subsection{Muluk (poverty solution)}

Muluk means that a leader is able to relieve his people from poverty and suffering to the main welfare. Muluk in everyday Javanese means 'lifting' food with bare hands. Muluk also means a leader who strives for his community to be more famous. Muluk is also behavior to raise ignorance and backwardness into the glow of noble 
civilization. More than that, a muluk leader must be able to raise the degree and dignity of his nation in the eyes of other nations in the world.

Arok has had a muluk sense since he is a student. Arok has his own concept of life, namely life is to be lived and to live. By this, he is recognized by his teacher as having the quality of a young man with a trident in hand who will be able to destroy the wrath, symbolized as the fusion of brahmana and satris who comes from this sudra.

"At the time Sang Hyang Mahadewa Bathara Guru sprinkled understanding on humans, at that time human life was lived. Yes, Supreme Master Father, then understanding was life, life was to love" (Toer, 1999: 67)

"Look at this," with the palm of his right hand he patted Arok's neck, "a young man, a Humalang, who with a trident in hand will be able to destroy Kunda. This is Arok, a man who knows how to deal with Tumapel Akuwu. Accept him, the fusion of brahmin and shatriya from this sudra" (Toer, 1999: 210)

After Arok is able to enter the Tumapel troops led by Tunggul Ametung, he slowly begins to rebel within Tumapel. When Arok is able to find a hidden gold mine belonging to Tunggul Ametung, he releases all the slaves employed in the gold mine. Arok raises their dignity with that freedom. The muluk sense shown by Arok further increases the people's confidence that Arok deserves to be a new leader in Tumapel.

"Hayam, follow them with your squad," Arok ordered. Then to all the slaves present, "From today on you are free..." (Toer, 1999: 301).

Once, an old friend of Arok's who has left him meets Arok in a battle. He questions about the stolen gold they have once obtained during the rebellion. He suspects Arok has taken the gold for his own benefit. He does this to influence Arok's soldiers to turn against Arok and go with him. In order to substantiate his pretext, he cooperates with a brahmana, but this brahmana is also not good, still greedy for worldly interests. Arok is not at all afraid to face this resistance. He loudly explains that the gold and treasures they have obtained during the rebellion have been channeled to the families of soldiers who have to survive and also to meet the needs of war such as weapons. He does not even take any of their gold or booty for his sake.

"You false Brahmin greedy for gold. Where did the spears and swords in all these people's hands come from? What do you think of the Brahmin Arya Artya? Who is helping their family, all these friends have left our brothers not our gold together? At least Arya Artya has never helped, even if it is only with a grain of rice. Do you think that only these people you can see need money?"

(Toer, 1999: 397).

\subsection{Melok (aspiration realization)}

This style can be realized in the form of dialogues of Arok in the novel. Melok is implied in the forms of action. The dialogues occur when Arok gathers with his soldiers and followers. Arok shows how he is able to voice the aspiration of his people, how he reveals things without hiding something, and how he considers all demands of his people as a trust for him. 
"That inability comes from self-governing, Dedes, inability to understand one's own subjects, their needs, their interests"

(Toer, 1999: 254).

Arok explains to Ken Dedes about the inability of Tunggul Ametung as a leader who is unable to understand his people. By showing this, Arok indirectly shows that he has the ability to understand his people. For him, by understanding the people we lead, we will also be able to run the government well.

Furthermore, Arok's melok is also shown by not hiding the truth about the fact that his adoptive father is the one who has brought several people into slavery in the gold mine of Tunggul Ametung. Arok does not hide it at all and openly asks them to forgive each other, so those who initially argue with each other forgive each other then.

"So Ki Bango Samparan was also made a slave by other people.

Henceforth it is no longer allowed, either because of gambling, debt or not being able to pay tribute. You understand? Sorry you guys, start today. Well, be friendly now with all the soldiers who have freed you!" (Toer, 1999: 303).

In addition, not hiding anything from the people being led is one of the main forms of attitude towards melok, where there is melok there must be an open system in leadership between the leader and the followers. This is a manifestation of the attitude that the people's mandate is a belief that must be guarded by a leader.

The realization of melok attitude is also shown by Arok in doing justice to anyone according to his abilities. This is a promise he makes to his followers. The justice given is not based on forgiveness and punishment, but according to the actions committed. If it deserves to be punished according to its people, it will be punished, and vice versa.

"Listen," Arok said to all present, as well as the soldiers who woke up from their slumber, "we do not give pardons and punishments. We give justice to everyone, to all to the best of our ability..."

(Toer, 1999: 351).

Arok's melok style is also shown to Tunggul Ametung. In an attack to the south, Arok shows his striking style to his followers. At that time, Tunggul Ametung is being cornered because it is attacked by the rebels. Arok and his followers feel that Tunggul Ametung begins to suspect them as part of the rebels. Arok cleverly reasons by questioning whether the agreement between Tunggul Ametung and his teacher, Lohgawe, still serves as a diversion to Tunggul Ametung's suspicions towards him and his followers. Arok continues to show his melok style to his followers by asserting that if Tunggul Ametung no longer follows the agreement, he and his followers have no obligation to obey him. Arok takes advantage of Tunggul Ametung's condition, short of troops and wedges between the rebel and Arok's troops.

"Your Majesty has not yet passed the order. So, while my troops are on alert like this, I want to get confirmation: is there an agreement with His Holiness Dang Hyang Lohgawe that Your Majesty still respects or not? Otherwise, there is now no obligation for us to Your Majesty" (Toer, 1999: 429). 
The word us refers to Arok and his followers. It shows that Arok's statement is not only his thought, but also of his followers. Arok melok is the aspiration related to the situation. This also reveals that Arok is really concerned with the demand of his followers as a trust for him. That is the point of melok style.

\subsection{Meluk (accomodation)}

The last style of Javanese political leadership is meluk, accommodating all people. Meluk is revealed by Ken Arok to people around him. He always shows his feeling and behaviors of sincere and deep love for his people. He shows a form of intimacy in leadership by bringing a sense of comfort, security, and peace to his people. Meluk is shown by Ken Arok to his teacher and followers. The meluk style shown by Arok is performed by paying attention to the person he respects. Arok thinks of all their interests in as much detail as possible. One of them is when he intends to visit his adoptive family, but at the same time the teacher is in trouble. Arok feels unable to leave his teacher in that condition. He then asks some of his friends to fulfill his promise to visit his adoptive parents by telling them to prepare all the needs his parents need, while Arok will stay to take care of his teacher's needs. In that way, every need can be resolved.

"One of you will leave early tomorrow morning for Kampundungan.

In the past few days, Father Mahaguru ajan still needed me. I can't leave him. Tell them to keep working while I'm not around. And be careful. Well, go to sleep!"' (Toer, 1999: 69).

Arok is very concerned about the safety of his friend by telling him to be careful on his journey later. This shows the closeness that exists between his friend and Arok who is mandated as the leader of his people by the members of his group.

Meluk style is also shown by Arok to other members of his adoptive family. Arok even asks one of his friends to keep his adoptive family from being dragged into slavery, even though it is only his adoptive family, Arok is so close and dear to them.

".......Tell the youths to protect Ki Bango. He cannot be dragged into slavery. And don't forget to tell Umang, I will come in a few weeks or months" (Toer, 1999: 97).

As a leader of the people, Arok shows his meluk style by not hesitating to mingle with his people. Every soldier who goes with him is so cared for, starting from the needs of clothing and food, to other needs, Arok has always shown a concern. Arok becomes a leader who provides a sense of comfort, security, and peace for his followers.

They set off, and Arok scrutinized the food and drink provided for himself and his guards (Toer, 1999: 351).

Arok not only cares about his own needs, but also the food and drink needs of each of his soldiers. Furthermore, Arok's meluk style is shown in terms of caste equality among the people when he is elected by acclamation as the leader of Tumapel after the fall of Tunggul Ametung. Arok tells his people not to fight with each other, even though they are sudra, wisynu, syiwa, even Buddha.

"I, Arok, am a sudra like all of you. Since it's all sudras, don't fight.

Be it Vishnu, Shiva, Buddha, Kalachakra and Tantrayana, don't fight because different people glorify the gods..." (Toer, 1999: 547). 
The dialogue above shows how Arok instructs his people not to fight each other because they are different in worshiping Gods. This method is used by Arok to accomodate 'meluk' of each of his people united in differences, with mutual respect.

\section{Conclusion}

The styles of Javanese political leadership in the novel Arok Dedes written by Pramoedya Ananta Toer refer to the Javanese political leadership known as 5Ms style: 1) melek (awareness) 2) melik (sense of ownership), 3) muluk (poverty solution), 4) melok (aspiration realization) and 5) meluk (accomodation). All of these data are sourced from one of the characters in the novel, Ken Arok, based on monolog or dialogue in the novel.

The styles of Javanese political leadership are also revealed by the character, Ken Arok in the forms of deeds and actions. This shows his personal quality as a candidate for a new leader in Tumapel. Arok shows his leadership style adapting the 5Ms styles in concrete actions during his rebellion against Tunggul Ametung. Arok is a rebel leader who cannot be defeated by Tunggul Ametung. This is because his leadership attitude is highly respected by his soldiers, so his soldiers are obedient, and they do not dare to betray. In his actions, Arok tries to fulfill the interests of his group. In other words, the interests of the group are above his own. This is the quality of Arok as the new leader in Tumapel after the fall of Tunggul Ametung.

\section{References}

Chemers, M. (2014). An Integrative Theory of Leadership. New York: Prince.

Cohen, D. (1997). Carl Rogers. A Critical Biography. London: Constable.

Davis, K. (2003). Pegaruh Seorang Pemimpin dalam Kesuksesan sebuah Organisai. (online). Retrieved from http://kep-or-modern. ( 3 March 2021).

Emir, Badegül Can. (2016) Literature and Psychology in the Context of The Interaction of Social Sciences. Khazar Journal of Humanities and Social Sciences, Volume 19, Number 4 Retrieved from https://jhss-khazar.org/wpcontent/uploads/2016/11/son.4._tURKEY_12.12.2016_1.pdf (3 March 2021)

Endraswara, Suwardi. (2013). Falsafah Kepemimpinan Jawa. Yogyakarta: Narasi.

Frankel, Jack R dan Norman E. Wallen.(2000). How to Design and Evaluate Research in Education. 2nd edition. New York: McGraw Hill Inc.

Kartono, Kartini, (1980). Pengantar Metodologi Research Sosial. Bandung: Bandung. Pradopo, Rachmat Djoko.(2002). Beberapa Teori Sastra, Metode Kritik dan Penerapannya. Yogyakarta: Pustaka Pelajar

Sangidu. (2004). Metode Penelitian Sastra, Pendekatan Teori, Metode dan Kiat. Yogyakarta: UGM.

Semi, M. Atar. (1989). Kritik Sastra. Bandung: Angkasa.

Soetopo, H. 2010. Kepemimpinan Pendidikan. Malang: FIP UM.

Toer, P. A., \& Isak, J. (2000). Arok Dedes. Bandung: Hasta Mitra.

Wellek, Rene and Warren Austin. (1977). Theory of Literature. New York: Harvest Book 